\title{
Cancer stem-like cells of glioblastoma characteristically express MMP-13 and display highly invasive activity
}

\author{
AKIHIRO INOUE $^{1}$, HISAAKI TAKAHASHI ${ }^{2,3}$, HIRONOBU HARADA ${ }^{1,3}$, SHOHEI KOHNO ${ }^{1}$, SHIRO OHUE ${ }^{1}$, \\ KANA KOBAYASHI $^{2}$, HAJIME YANO ${ }^{2,3}$, JUNYA TANAKA ${ }^{2,3}$ and TAKANORI OHNISHI ${ }^{1}$ \\ Departments of ${ }^{1}$ Neurosurgery and ${ }^{2}$ Molecular and Cellular Physiology, Graduate School of Medicine, Ehime University; \\ ${ }^{3}$ Department of Basic and Clinical Neuroscience, Ehime Proteo-Medicine Research Center, Toon, Ehime 791-0295, Japan
}

Received June 17, 2010; Accepted August 3, 2010

DOI: 10.3892/ijo_00000764

\begin{abstract}
Glioblastoma is the most malignant type of primary brain tumor that has been shown to contain a small population of cancer stem cells. Recent studies have suggested that cancer stem cells cause tumor recurrence based on their resistance to radiotherapy and chemotherapy. Although the highly invasive nature of glioblastoma cells is also implicated in the failure of current therapies, it is not clear whether cancer stem cells are involved in invasiveness. In this study, we isolated tumor sphere-forming cells bearing cancer stemlike characteristics such as self-renewal, multipotency, drug-resistibility, and in vivo tumorigenicity, from the human glioblastoma cell line U251, under serum-free neural stem cell culture condition, and assessed their migratory and invasive ability. These cells showed enhanced migratory and invasive ability on both Matrigel and organotypic brain slices compared to parental U251 cells. The expression of matrix metalloproteinase (MMP)-13 was specifically expressed in tumor sphere-forming cells derived from U251 and primary human glioma cells. Knockdown of MMP-13 expression by shRNA suppressed the migration and invasion of these cells. The results suggest that the highly invasive potential of cancer stem cells depends on MMP-13 enzymatic activity, thus MMP-13 might be a potential therapeutic target for glioblastomas.
\end{abstract}

\section{Introduction}

Accumulating evidence indicates that a variety of malignant tumors have been found to contain their own stem cells. These cells, referred to as cancer stem cells (CSCs), have the potential for self-renewal and differentiation into multilineage cells (1). Glioblastoma (GBM) is one of the tumors from

Correspondence to: Dr Hisaaki Takahashi, Department of Molecular and Cellular Physiology, Ehime University Graduate School of Medicine, Toon, Ehime 791-0295, Japan

E-mail: hisaaki@m.ehime-u.ac.jp

Key words: glioblastoma, cancer stem cells, invasion which CSCs have been isolated $(2,3)$. CSCs of GBM have been shown to be resistant to radiotherapy due to their increased activity of the DNA damage checkpoint response (4). CSCs more strongly resist a variety of chemotherapeutic agents than non-CSCs (5). These observations suggest that, irrespective of the cause, CSCs may persist even after various intensive therapies and may be the cause of recurrence.

The extracellular matrix (ECM) is a dynamic environment that plays a pivotal role in regulating cellular functions. Tumor cells may invade the surrounding normal tissue while digesting ECM by secreting proteolytic enzymes, such as matrix metalloproteinases (MMPs) and plasminogen activator (6). Although there is little ECM in the extracellular milieu of the brain, in contrast to most other tissues, the brain parenchyma contains a relatively amorphous matrix that contains fibrillary collagen, hyaluronic acid and other fibrous proteins (6). Furthermore, ECM proteins such as interstitial collagen, fibronectin, and laminin are present in the border area between normal brain and glioma cells (7).

MMPs are a family of structurally related enzymes that play a central role in tumor invasion by degrading ECM macromolecules. MMPs can be divided into subgroups of collagenase, gelatinase, stromelysins, matrilysins, and membrane-type MMPs (8). A growing body of literature has documented a strong correlation between brain tumor malignancy and MMP activity level (9-11). MMP-2 and MMP-9 are highly expressed in glioma cells to create space necessary to invade the surrounding brain parenchyma $(12,13)$. Yeh et al recently demonstrated that rat C6 glioma cells with induced expression of MMP-13, a collagenolytic MMP, had higher migratory and invasive activity in vitro (14). Furthermore, several MMPs including MMP-2 and MMP-9 can activate some growth factors that are implicated in GBM motility and proliferation, such as TGF- $\beta$ by releasing them from the ECM (15). Thus, understanding the mechanisms underlying the highly invasive potential of GBM cells through MMPs may lead to a radical cure for such intractable neoplasms.

Although recent literature indicates that CSCs might be responsible for tumor initiation, progression and recurrence, little is known about whether CSCs are involved in invasiveness, a hallmark of malignant gliomas. In this study, we isolated cancer stem-like cells derived from the human glioma 
cell line U251 by allowing the cells to make spherical aggregates and then evaluated their invasive potential. Compared to the parental U251 cells, the cancer stem-like cells were much more capable of migration and invasion, and this invasiveness was primarily dependent on the enzymatic activity of MMP-13 but not MMP-2 or MMP-9. These results suggest that CSCs are responsible for the highly invasive potential of glioblastomas.

\section{Materials and methods}

Cell culture. Human glioma cell line U251 was cultured in Dulbecco's modified Eagle's medium (DMEM) (Wako, Osaka, Japan) supplemented with $10 \%$ fetal bovine serum (FBS), $4.5 \mathrm{~g} / 1$ glucose, and penicillin/streptomycin/amphotericin B mixture (Wako). To establish U251 cells that stably express enhanced green fluorescence protein (EGFP) termed GFP-U251, U251 cells were transfected with pEGFP-C1 (Clontech, Mountain View, CA) using Lipofectamine 2000 reagent (Invitrogen, Grand Island, NY) according to the manufacturer's instructions. Cells stably expressing EGFP were selected by culturing in medium containing G418 selection ( $500 \mu \mathrm{g} / \mathrm{ml}$; Invitrogen) and cell sorting by FACS ARia (Becton-Dickinson, San Jose, CA). For knockdown experiments, GFP-U251 cells were transfected with MMP-13 small hairpin (sh) RNA plasmid containing a 21-bp shRNA sequence 5'-GCTCCGAGAAATGCAGTCTTT-3' of human MMP-13 (pLKO.1/MMP-13 shRNA; Sigma, St. Louis, MO) or non-target control shRNA plasmid (pLKO.1/non-target shRNA; Sigma) using Lipofectamine 2000 reagent. Cells stably expressing shRNA were selected by culturing in medium containing puromycin ( $2 \mu \mathrm{g} / \mathrm{ml}$; Sigma).

Some subpopulations of U251, GFP-U251, non-target shRNA-U251, or MMP-13 shRNA-U251 cells formed round cell aggregates or spheres when the cells were cultured in serum-free DMEM containing $10 \mu \mathrm{g} / \mathrm{ml}$ bovine insulin, $5.5 \mu \mathrm{g} / \mathrm{ml}$ human transferrin, $6.7 \mathrm{ng} / \mathrm{ml}$ sodium selenite (ITS mixture; Invitrogen), $100 \mu \mathrm{g} / \mathrm{ml}$ bovine serum albumin (BSA; Sigma), the penicillin/streptomycin/amphotericin B mixture, recombinant human epidermal growth factor (EGF; $10 \mathrm{ng} / \mathrm{ml}$ ), basic fibroblast growth factor (bFGF; $10 \mathrm{ng} / \mathrm{ml}$ ), and platelet derived growth factor-AA (PDGF-AA; $10 \mathrm{ng} / \mathrm{ml}$ ). Growth factors were purchased from Peprotech, London, UK. In this report, the serum-free medium containing the growth factors is called sphere medium.

Human GBM specimens and primary cell culture. Surgically resected tumor specimens from GBM patients were obtained after informed consent with approval by the local ethics committee at Ehime University Hospital. GBM tissues were mechanically minced, digested with $0.1 \%$ trypsin, and then triturated with a Pasteur pipette. Cells were passed through a 70- $\mu \mathrm{m}$ strainer (Becton-Dickinson Falcon), and resuspended in high glucose DMEM supplemented with $10 \%$ FBS. Sphere formation using the 3-6 passaged-cells was performed in the same manner as U251.

RNA isolation and RT-PCR. Total RNA was collected using Isogen (Nippon Gene, Tokyo, Japan) according to the manufacturer's instructions. cDNA was obtained from DNase I- treated RNA (3 $\mu \mathrm{g})$ by reverse transcription using M-MLV Reverse Transcriptase (Invitrogen) and oligo(dT) $)_{15}$ primer as previously described (16). DNA fragments were amplified with GoTaq DNA polymerase (Promega, Madison, WI). The PCR conditions were as follows: $94^{\circ} \mathrm{C}$ for $1 \mathrm{~min}$, followed by 22 (ß-actin), 35 (CD133), or 30 (other genes) cycles of $94^{\circ} \mathrm{C}$ for $30 \mathrm{sec}, 56^{\circ} \mathrm{C}$ for $30 \mathrm{sec}$, and $72^{\circ} \mathrm{C}$ for $1 \mathrm{~min}$. The primer sequences, the accession number, and product size are listed in Table I.

Flow cytometry analysis. Tumor sphere-forming cells and U251 cells were dissociated using $0.25 \%$ trypsin, fixed with $4 \%$ paraformaldehyde (PFA) and stained with phycoerythrin (PE)-conjugated anti-CD133/2 (1:10; Milteny Biotec, Germany) or control-IgG isotype (Becton-Dickinson, Franklin Lakes, NJ) antibodies, and then analyzed by FACS Calibur flow cytometer and CellQuest software (Becton-Dickinson).

Secondary tumor sphere formation assay. Primary tumor spheres with 100-200 cells/sphere were dissociated using $0.25 \%$ trypsin and seeded at a density of one cell in $100 \mu 1$ of sphere medium in 96-well plates. Cells were fed with $20 \mu \mathrm{l}$ of sphere medium every 3 days. Five 96-well plates were generated for cells derived from either U251 cells or tumor spheres, and only the wells that contained single cells were marked and analyzed 21 days later regardless of whether secondary tumor spheres were formed. The percentage of wells that generated secondary tumor spheres was determined.

Western blot and immunoprecipitation analysis. Cells grown on poly-L-lysine coated dishes were lysed with Laemmli's sample solution. The lysates were electrophoresed, transferred onto nitrocellulose membrane, and immunoblotted with antibodies to B-actin (mouse monoclonal; Sigma) and MMP-13 (rabbit polyclonal; Abcam, Cambridge, UK). Immunoreaction was developed using nitro blue tetrazolium and 5-bromo-4chloro-3-indolyl phosphate.

To detect secreted MMP-13, media conditioned by tumor spheres or parental U251 cells were incubated with mouse monoclonal anti-human MMP-13 antibody (Daiichi Fine Chemical, Toyama, Japan) and protein A/G agarose slurry at $4^{\circ} \mathrm{C}$ overnight. The resulting immunocomplex was washed three times with lysis buffer consisting of $50 \mathrm{mM}$ Tris- $\mathrm{HCl}$ ( $\mathrm{pH} 7.5), 0.5 \mathrm{M} \mathrm{NaCl}, 1 \%$ Triton $\mathrm{X}-100,10 \%$ glycerol, and protease inhibitor cocktail (Sigma); it was then subjected to Western blot analysis using rabbit polyclonal anti-human MMP-13 antibody.

In vivo xenograft experiments. U251 cells and sphere-forming cells were suspended at $5 \times 10^{2}-1 \times 10^{6}$ cells in $100 \mu 11: 1$ phosphate-buffered saline (PBS)/Matrigel (Becton-Dickinson), and subcutaneously implanted over the right thigh of 6-weekold male BALB/c nude mice (Charles River). Tumor growth was monitored weekly. Mice were sacrificed at 2, 3, 4, 6, and 8 weeks after implantation, and tumors were dissected out and the tumor volume and weight were measured. Tumor volume $(\mathrm{V})$ was determined by the equation $\mathrm{V}=\mathrm{L} \mathrm{x} \mathrm{W}^{2} \times 0.5$, where $\mathrm{L}$ is the length and $\mathrm{W}$ is the width of the tumor. For orthotopic transplantation, cells were suspended in PBS ( $1 \times 10^{5}$ cells $\left./ \mu 1\right)$. Six-week-old NOD-SCID (Charles River) 
Table I. Oligonucleotide primers used in this study for RT-PCR.

\begin{tabular}{|c|c|c|c|}
\hline Genes & Accession no. & Sense/antisense & Size (bp) \\
\hline CD133 & NM_006017 & $\begin{array}{l}\text { 5'-TTGAGGAACTCCCTGAAAAG-3' } \\
\text { 5'-ACAAATTCAAGGGGTCGATA-3' }\end{array}$ & 384 \\
\hline Oct-3/4 & NM_002701 & $\begin{array}{l}\text { 5'-GACAGGGGGAGGGGAGGAGCTAGG-3' } \\
\text { 5'-CTTCCCTCCAACCAGTTGCCCCAAAC-3' }\end{array}$ & 118 \\
\hline Nanog & NM_024866 & $\begin{array}{l}\text { 5'-CAGCCCCGATTCTTCCACCAGTCCC-3' } \\
\text { 5'-CGGAAGATTCCCAGTCGGGTTCACC-3' }\end{array}$ & 366 \\
\hline Sox-2 & NM_003106 & $\begin{array}{l}\text { 5'-GGGAAATGGGAGGGGTGCAAAAGAGG-3' } \\
\text { 5'-TTGCGTGAGTGTGGATGGGATTGGTG-3' }\end{array}$ & 125 \\
\hline Klf-4 & NM_004235 & $\begin{array}{l}\text { 5'-ACGATCGTGGCCCCGGAAAAGGACC-3' } \\
\text { 5'-TGATTGTAGTGCTTTCTGGCTGGGCTCC-3' }\end{array}$ & 698 \\
\hline Bmil & NM_005180 & $\begin{array}{l}\text { 5'-AGGAGAGGTTGCAGATGAAG-3' } \\
\text { 5'-GCTGGGCATCGTAAGTATCT-3' }\end{array}$ & 162 \\
\hline MMP-1 & NM_002421 & $\begin{array}{l}\text { 5'-ATTCTACTGATATCGGGGCTTTGA-3' } \\
\text { 5'-ATGTCCTTGGGGTATCCGTGTAG-3' }\end{array}$ & 304 \\
\hline MMP-2 & NM_004530 & $\begin{array}{l}\text { 5'-GCAGTTTGCTTTGTATGCAC-3' } \\
\text { 5'-TGGAGAAGAGACTCGGTAGG-3' }\end{array}$ & 185 \\
\hline MMP-3 & NM_002422 & $\begin{array}{l}\text { 5'-ATGCCCACTTTGATGATGATGAAC-3' } \\
\text { 5'-CCACGCCTGAAGGAAGAGATG-3' }\end{array}$ & 338 \\
\hline MMP-7 & NM_002423 & $\begin{array}{l}\text { 5'-GAGTGCCAGATGTTGCAGAA-3' } \\
\text { 5'-AAATGCAGGGGGATCTCTTT-3' }\end{array}$ & 168 \\
\hline MMP-9 & NM_004994 & $\begin{array}{l}\text { 5'-CCAGTTTCCATTCATCTTCC-3' } \\
\text { 5'-CGAGTACTCCTTACCCAGGA-3' }\end{array}$ & 214 \\
\hline MMP-10 & NM_002425 & $\begin{array}{l}\text { 5'-ATTGATGCAGCTGTTTCTGA-3' } \\
\text { 5'-TCAACCTTAGGCTCAACTCC-3' }\end{array}$ & 152 \\
\hline MMP-13 & NM_002427 & $\begin{array}{l}\text { 5'-CCCAGGAATTGGTGATAAAG-3' } \\
\text { 5'-ATTACCCCAAATGCTCTTCA-3' }\end{array}$ & 195 \\
\hline bcrp1 & NM_004827 & $\begin{array}{l}\text { 5'-GGCCTCAGGAAGACTTATGT-3' } \\
\text { 5'-AAGGAGGTGGTGTAGCTGAT-3' }\end{array}$ & 341 \\
\hline mdr1 & NM_000927 & $\begin{array}{l}\text { 5'-CACGTGGTTGGAAGCTAACC-3' } \\
\text { 5'-GAAGGCCAGAGCATAAGATGC-3' }\end{array}$ & 317 \\
\hline mrp1 & NM_004996 & $\begin{array}{l}\text { 5'-AAGACCAAGACGTATCAGGT-3' } \\
\text { 5'-CAATGGTCACGTAGACGGCAA-3' }\end{array}$ & 258 \\
\hline B-actin & NM_031144 & $\begin{array}{l}\text { 5'-AGAAGAGCTATGAGCTGCCTGACG-3' } \\
\text { 5'-TACTTGCGCTCAGGAGGAGCAATG-3' }\end{array}$ & 301 \\
\hline
\end{tabular}

mice were anesthetized with pentobarbital and placed in the stereotactic frame using ear bars. A hole was made in the skull $2.0 \mathrm{~mm}$ lateral to the Bregma. Cell suspension $(3 \mu \mathrm{l})$ was transplanted into the right striatum $3.0 \mathrm{~mm}$ below the surface of the brain using a Hamilton syringe. When mice developed neurological deficits, they were sacrificed, and fixed with $4 \%$ PFA and the dissected brain were sliced into $5-\mu \mathrm{m}$-thick coronal sections using a cryostat as described previously (17). Brain sections were then subjected to hematoxylin and eosin $(\mathrm{H} \& \mathrm{E})$ staining. All animal experiments were performed in 
A
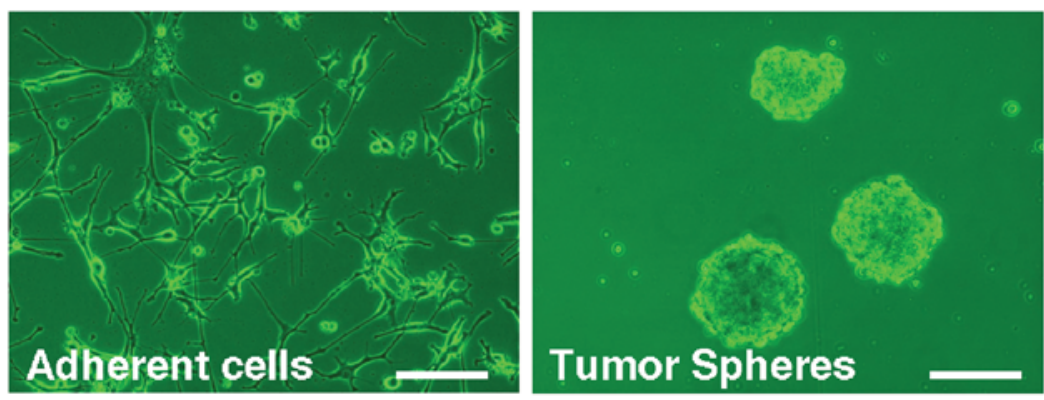

B

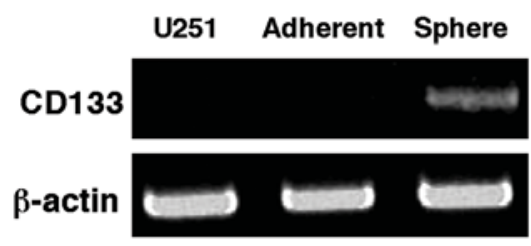

D

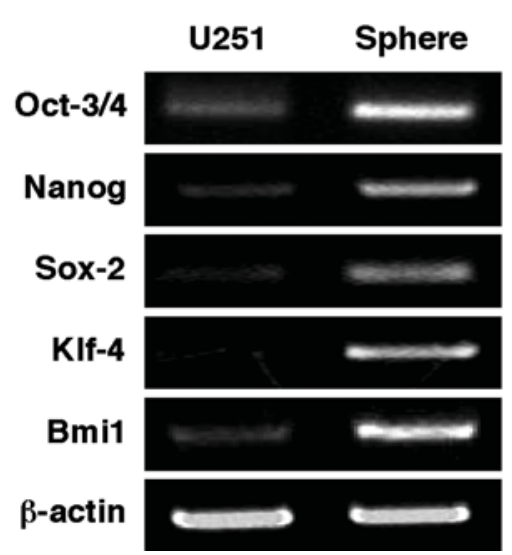

C
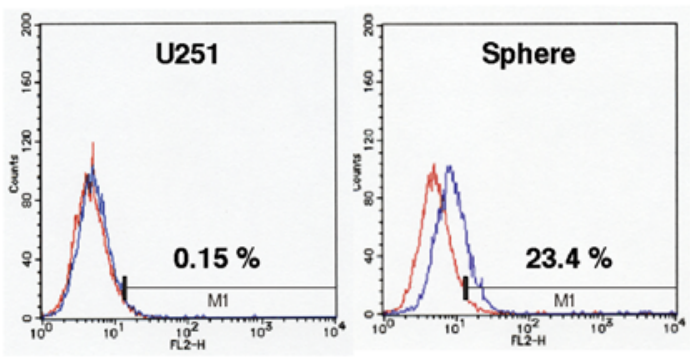

$\mathbf{E}$

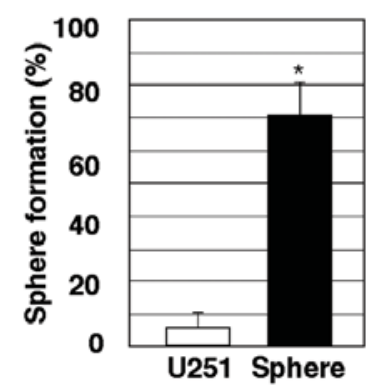

$\mathbf{F}$

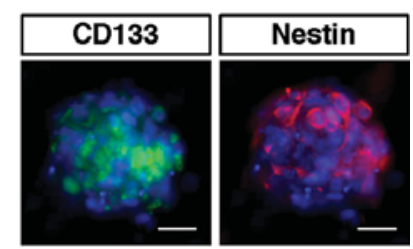

Figure 1. Isolation and characterization of U251-derived tumor spheres. (A) U251 cells were grown in sphere medium for 2 weeks. The morphology of adherent cells and developed tumor spheres are shown. Scale bar, $100 \mu \mathrm{m}$. (B) Expression of the stem cell marker CD133 mRNA in U251 and tumor spheres. Representative RT-PCR data are shown. Expression of B-actin mRNA was used as an internal control. (C) Flow cytometry analysis for CD133 on U251 and tumor sphere-forming cells. Dissociated cells were stained either with isotype IgG control (red line) or anti-CD133/2 antibody (blue line) conjugated with PE before the analysis. The percentage of CD133-positive cells in the total population is shown. (D) Expression of the stemness-related gene mRNAs in U251 and tumor spheres. Representative RT-PCR data are shown. (E) Tumor spheres exhibited self-renewal potential. Dissociated-tumor spheres were seeded at a density of one cell/well in 96-well plates and cultured for 21 days in sphere medium. The percentage of wells that generated secondary tumor spheres was determined. Values are expressed as mean \pm SD from triplicate experiments. ${ }^{*} \mathrm{P}<0.0001$. (F) Secondary tumor spheres retained the expression of stem cell markers, CD133 (green) and nestin (red). Nuclei were labeled with Hoechst 33258 (blue). Scale bar, $50 \mu \mathrm{m}$.

accordance with the guidelines of the Ehime University Committee for Ethics of Animal Experimentation.

Invasion assay in a brain slice model. Rat brain slice cultures for an invasion assay were prepared as described previously $(18,19)$. In brief, whole brains were quickly removed from 2-day-old neonatal Wistar rats (Charles River) and placed in Hanks' balanced salt solution (HBSS; Invitrogen). The brains were mounted on a stage of a microslicer (Dosaka EM, Kyoto, Japan), cut into $500 \mu$ m-thick coronal slices, and then transferred onto 30-mm Millicell-CM inserts with $0.4-\mu \mathrm{m}$ pores
(Millipore) in 6-well culture plates. The outer-well contained $1.0 \mathrm{ml}$ of brain slice medium $(50 \%$ Eagle's minimal essential medium with HEPES, 25\% HBSS, 25\% FBS, $6.5 \mathrm{mg} / \mathrm{ml}$ glucose, and penicillin/streptomycin/amphotericin B mixture). Brain slices were incubated at $37^{\circ} \mathrm{C}$ in a humidified atmosphere of $95 \%$ air and $5 \% \mathrm{CO}_{2}$.

Cell aggregates, called spheroids in this study, distinct from the spheres consisted of cancer stem-like cells, were prepared as follows: GFP-U251 cells $\left(2.0 \times 10^{5}\right)$ were seeded to $35-\mathrm{mm}$ culture dishes for suspension culture, and incubated at $37^{\circ} \mathrm{C}$ in a humidified atmosphere of $95 \%$ air and $5 \% \mathrm{CO}_{2}$ 
for $12-18 \mathrm{~h}$ while continuously agitating at a speed of $30 \mathrm{rpm}$ on a reciprocating shaker. Then, the spheroids were formed with a diameter 200-300 $\mu \mathrm{m}$. The spheroid or the sphere derived from GFP-U251 was placed on the corpus callosum of a brain slice, and cocultured at $37^{\circ} \mathrm{C}$ for $48 \mathrm{~h}$. The depth and expanse of invasion by the spheroid or the sphere was evaluated with an inverted confocal laser-scanning microscope (CLSM) (Nikon A1, Nikon, Japan).

Immunohistochemical staining of spheres invading into the brain slices. MMP-13 expression of tumor spheres invading brain slices was immunohistochemically analyzed. The slices were washed with PBS and fixed in $4 \%$ PFA at $48 \mathrm{~h}$ after starting the invasion assay. After inhibition of endogenous peroxidase activity, the slices were incubated in Tris-buffered saline containing $0.1 \%$ Tween-20 (TBSt) containing $1 \mathrm{mg} / \mathrm{ml}$ $\mathrm{BSA}$, and then incubated with a normal rabbit $\mathrm{IgG}$ or an anti-human MMP-13 polyclonal antibody $(1: 1000)$ at $4^{\circ} \mathrm{C}$ overnight. The slices were further incubated with a biotinylated goat anti-rabbit $\operatorname{IgG}$ antibody for $1 \mathrm{~h}$ at room temperature followed by incubation with streptavidin-peroxidase (Labvision, Fremont, CA) for $1 \mathrm{~h}$. Immunoreaction was visualized with 3-amino-9-etylcarbazole as chromogen (Labvision).

Statistical analysis. Values are expressed as mean \pm standard deviation (SD) and subjected to analysis of variance followed by a two-tailed Student's t-test (unpaired). Significance was set at $\mathrm{P}<0.05$.

\section{Results}

Tumor spheres from U251 glioma cell line express CD133 and have cancer stem cell phenotypes. To determine whether a subpopulation of self-renewing cancer stem-like cells, such as SP (side population) cells, exist in the human glioma cell line U251, we cultured U251 cells in serum-free sphere medium containing EGF, bFGF, and PDGF. Under this culture condition, most cells formed floating neurosphere-like cell aggregates, termed tumor spheres, within 2 weeks (Fig. 1A, right). The remaining cells that did not form tumor spheres adhered to the bottom of the culture dish, and did not significantly proliferate (Fig. 1A, left). We next investigated the expression of CD133 antigen, a putative brain tumor stem-like cell marker (3), by tumor spheres. CD133 mRNA was only expressed by spheres, but neither by U251 nor adherent non-tumor sphere-forming cells (Fig. 1B). Furthermore, flow cytometric analysis revealed that tumor sphereforming cells, but not parental U251 cells, significantly expressed CD133 antigen (Fig. 1C). In addition to CD133 expression, stemness-related genes, Oct-3/4, Nanog, Sox-2, Klf-4 and Bmi1, were more highly expressed by tumor sphere-forming cells than parental cells (Fig. 1D). Tumor spheres were dissociated and plated into 96-well plates as single cells per well; then, secondary spheres derived from single cells were counted to examine whether sphere-forming cells possess self-renewing ability. A total of $70.5 \pm 9.89 \%$ of single cells derived from tumor spheres formed secondary spheres, whereas $6.1 \pm 4.47 \%$ of single cells derived from parental U251 cells formed secondary spheres (Fig. 1E). The morphology of secondary tumor spheres was indistinguishable
Table II. In vivo tumorigenicity of U251 and tumor sphereforming cells.

\begin{tabular}{lccc}
\hline Cell & $\begin{array}{c}\text { Injected cell } \\
\text { number }\end{array}$ & $\begin{array}{c}\text { Tumor } \\
\text { formation }\end{array}$ & $\begin{array}{c}\text { Latency }^{\mathrm{a}} \\
\text { (days) }\end{array}$ \\
\hline U251 & $1.0 \times 10^{6}$ & $8(\mathrm{n}=8)$ & $22.8 \pm 3.2$ \\
& $5.0 \times 10^{5}$ & $8(\mathrm{n}=8)$ & $40.8 \pm 5.3$ \\
& $1.0 \times 10^{5}$ & $10(\mathrm{n}=10)$ & $51.7 \pm 3.9$ \\
& $1.0 \times 10^{4}$ & $0(\mathrm{n}=10)$ & - \\
& $5.0 \times 10^{3}$ & $0(\mathrm{n}=6)$ & - \\
& $1.0 \times 10^{3}$ & $0(\mathrm{n}=6)$ & - \\
& $1.0 \times 10^{6}$ & $8(\mathrm{n}=8)$ & $17.0 \pm 3.7$ \\
& $5.0 \times 10^{5}$ & $8(\mathrm{n}=8)$ & $26.0 \pm 3.4$ \\
& $1.0 \times 10^{5}$ & $10(\mathrm{n}=10)$ & $33.4 \pm 3.1$ \\
& $1.0 \times 10^{4}$ & $6(\mathrm{n}=6)$ & $42.0 \pm 18.3$ \\
& $5.0 \times 10^{3}$ & $6(\mathrm{n}=6)$ & $47.3 \pm 5.4$ \\
$1.0 \times 10^{3}$ & $6(\mathrm{n}=6)$ & $53.0 \pm 8.1$ \\
& $5.0 \times 10^{2}$ & $6(\mathrm{n}=6)$ & $57.1 \pm 8.1$ \\
\hline
\end{tabular}

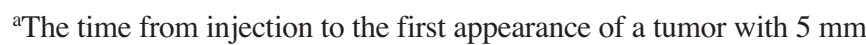
diameter.

from that of primary spheres, and these secondary spheres were immunoreactive to antibodies to CD133 and nestin, a marker for neural stem/progenitor cells, suggesting that the U251 cell line contains stem-like cells with a self-renewing ability (Fig. 1F). We further defined that tumor sphereforming cells possessed the other characteristics of cancer stem cells, such as multipotency, and drug-resistibility (data not shown). These data corroborate the assertion that tumor spheres generated from U251 cells are enriched with cancer stem-like cells.

Tumorigenicity of tumor spheres. Because strong tumorigenicity is one of the hallmarks of CSCs, we compared the tumorigenicity of tumor sphere-forming cells with that of parental U251 cells (Fig. 2). Subcutaneous implantation of $1 \times 10^{6} \mathrm{U} 251$ cells or tumor sphere-forming cells into the right thigh of nude mice developed tumor masses in all mice (Fig. 2A and Table II). However, the tumor masses dissected from mice implanted with sphere-forming cells $(3.3 \pm 0.8 \mathrm{~g}$ and $2562 \pm 512 \mathrm{~mm}^{3}$ ) were heavier by 6.85 -fold in weight and 10.1-fold larger in volume at 8 weeks than those from mice implanted with parental U251 cells $(0.48 \pm 0.14 \mathrm{~g}$ and $\left.253 \pm 85 \mathrm{~mm}^{3}\right)$, regardless their comparable cell growth rate (Fig. 2B and data not shown). In contrast, adherent cells hardly developed tumors and only a small tumor was formed at 8 months after transplantation. Furthermore, tumor masses were palpable at $17.0 \pm 3.3$ days after implantation with tumor spheres and 22.8 \pm 3.2 days after implantation with parental U251 cells (Table I). Only 500 tumor sphere-forming cells generated a palpable tumor mass within two months in all mice, whereas $1 \times 10^{4}$ parental U251 cells were unable to generate a palpable tumor mass. 
A

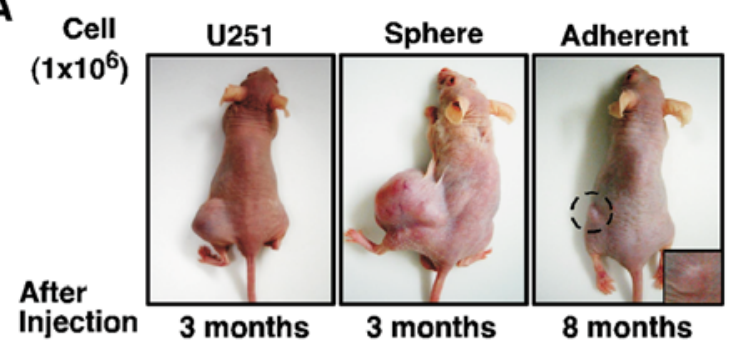

B

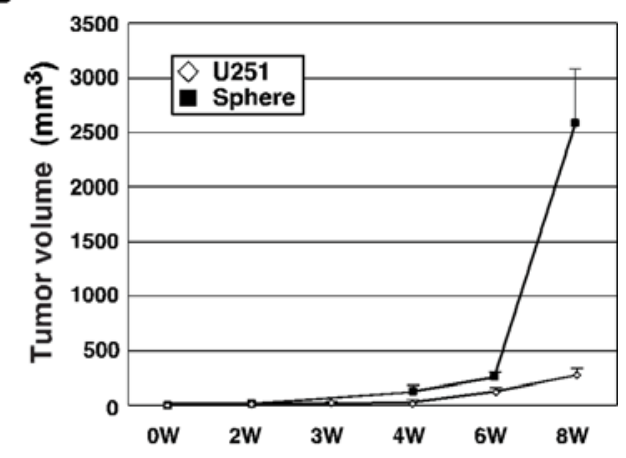

C
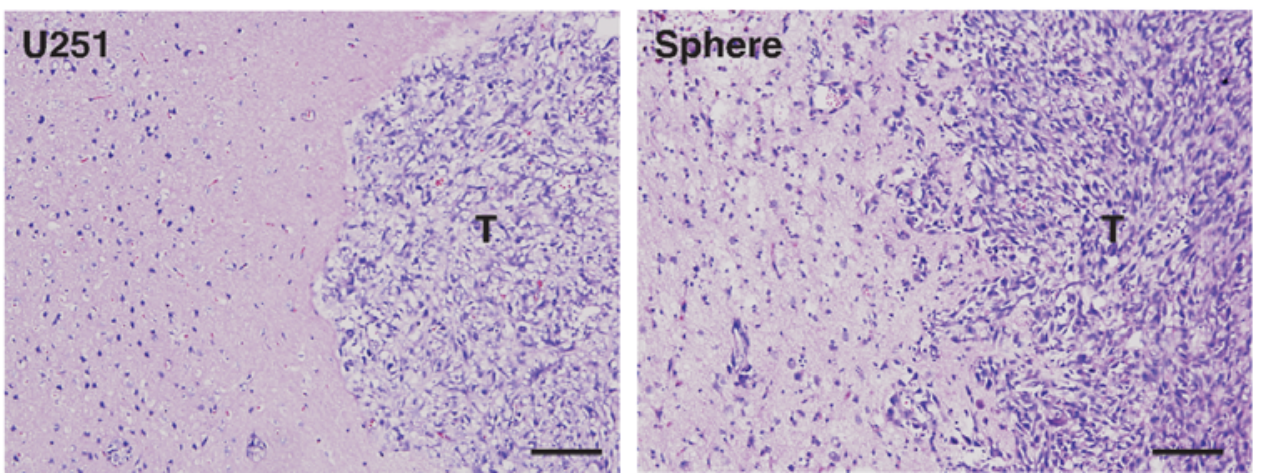

Figure 2. In vivo tumorigenicity of tumor sphere-forming cells. (A) U251, tumor sphere-forming cells, and adherent cells (1x10 ${ }^{6}$ cells) were subcutaneously injected into the right thigh of male nude mice. The resulting tumor xenografts at the indicated times are shown. The insert shows a high-magnification view of the circled area. (B) The volumes of tumors taken from nude mice at the indicated times are shown. Values are represented as mean \pm SD ( $=4$ ). (C) U251 and tumor sphere-forming cells $\left(3 \times 10^{5}\right.$ cells) were orthotopically implanted into the brains of NOD-SCID mice. Coronal brain sections at 5 weeks after cell transplantation were stained with H\&E. T indicates tumor. Scale bar, $100 \mu \mathrm{m}$.

To examine the phenotype of orthotopically implantation, $\mathrm{U} 251$ and tumor sphere-forming cells $\left(3 \times 10^{5}\right.$ cells $)$ were implanted in the right striatum of NOD-SCID mice, and all the mice developed brain tumors by 5-6 weeks after implantation. Histopathological investigation of xenografts showed that brain tumors of parental U251 cells were clearly delineated by the normal brain tissue (Fig. 2C, left). Whereas tumors of tumor sphere-forming cells were vaguely delineated, indicating their active invasion (Fig. 2C, right). Thus, tumor sphereforming cells possess the highly motile and invasive nature.

Invasion of glioma spheres observed in a rat brain slice model. We therefore evaluated their migratory and invasive ability of tumor sphere-forming cells, since such abilities are critical for the lethal outcome of GBMs. To examine the invasive ability into a brain tissue, a rat brain slice model was used. In this model, the invasive ability of glioma cells was evaluated through three-dimensional serial observation using CLSM. A spheroid or a tumor sphere, both of which were made of parental GFP-U251 cells, were placed on a brain slice on the corpus callosum as illustrated in Fig. 3A. As shown in Fig. 3B, some cells migrated out of the spheroid and tumor sphere, and those cells were allowed to move in the slice for $48 \mathrm{~h}$. The three-dimensional movement of the EGFP-expressing cells was evaluated through serial optical sections from the surface to the bottom of the slice. The cells from the tumor spheres intensively invaded the brain slice (maximum depth from the surface of the slice: $-69 \pm 3.2 \mu \mathrm{m}$ ), and appeared to spread along the neuronal fibers of the corpus callosum. These migration patterns in the brain slices are similar to those in clinical situations called butterfly glioma, caused by migration of glioma cells to the contralateral hemisphere through the corpus callosum (20). Whereas, most cells of the spheroid remained in the spheroid and invaded the brain slice to a depth of $-50 \mu \mathrm{m}$ (maximum depth: $-57 \pm 5.8 \mu \mathrm{m}$ ) (Fig. 3B and C). Fig. 3D shows the distribution of cells of the spheres and spheroids in the brain slices. Theses cells showed similar behavior with a transwell chamber assay and an in vitro Matrigel invasion assay (data not shown). Thus, tumor sphereforming cells had stronger migratory and invasive ability than spheroids in all evaluated serial sections.

Involvement of MMP-13 in invasive ability of tumor spheres. The aggressive invasive ability of tumor sphere-forming cells may be correlated with MMP activity. RT-PCR analysis revealed the expression of MMP-13 mRNA in tumor sphereforming cells (Fig. 4A). MMP-2 and MMP-7 mRNA were expressed in both tumor sphere-forming cells and parental U251, but their levels of expression did not differ. MMP-1, MMP-3, MMP-9, and MMP-10 mRNA were not detected in either type of cells. The specific expression of MMP-13 mRNA in tumor sphere-forming cells was also evident in 
A

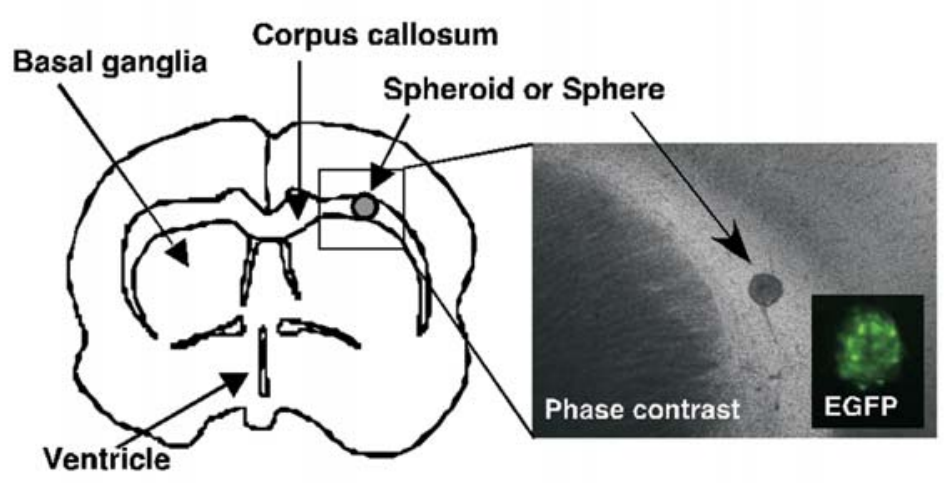

B

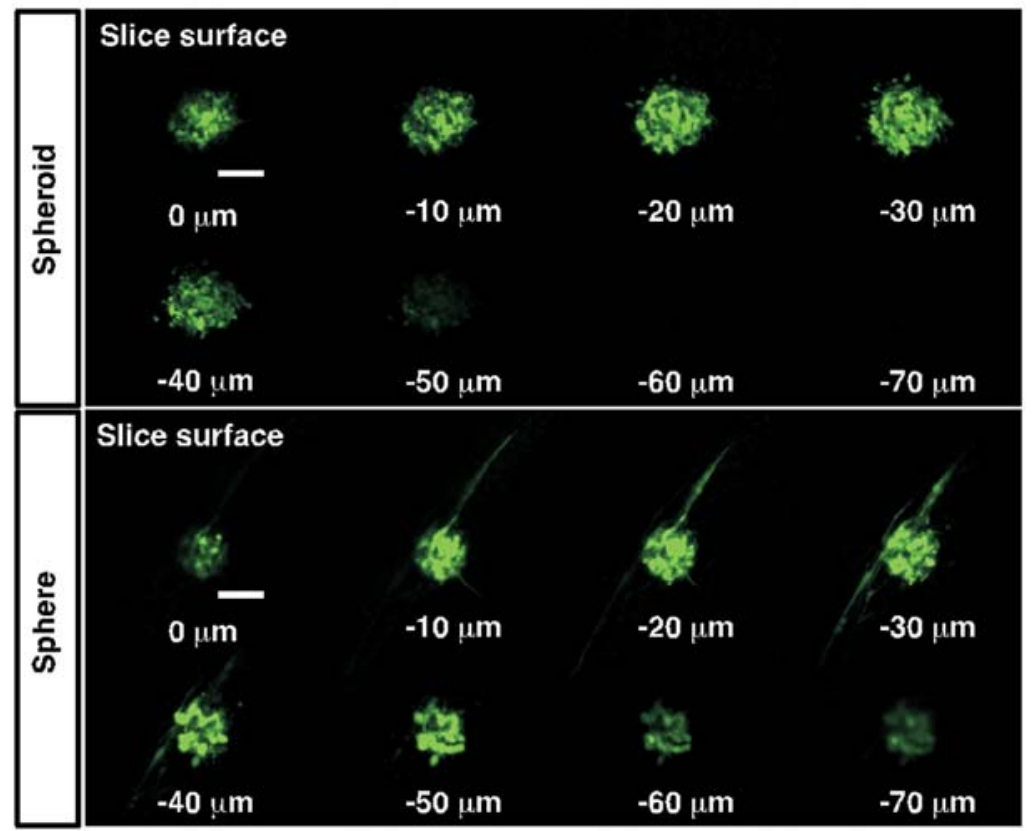

C
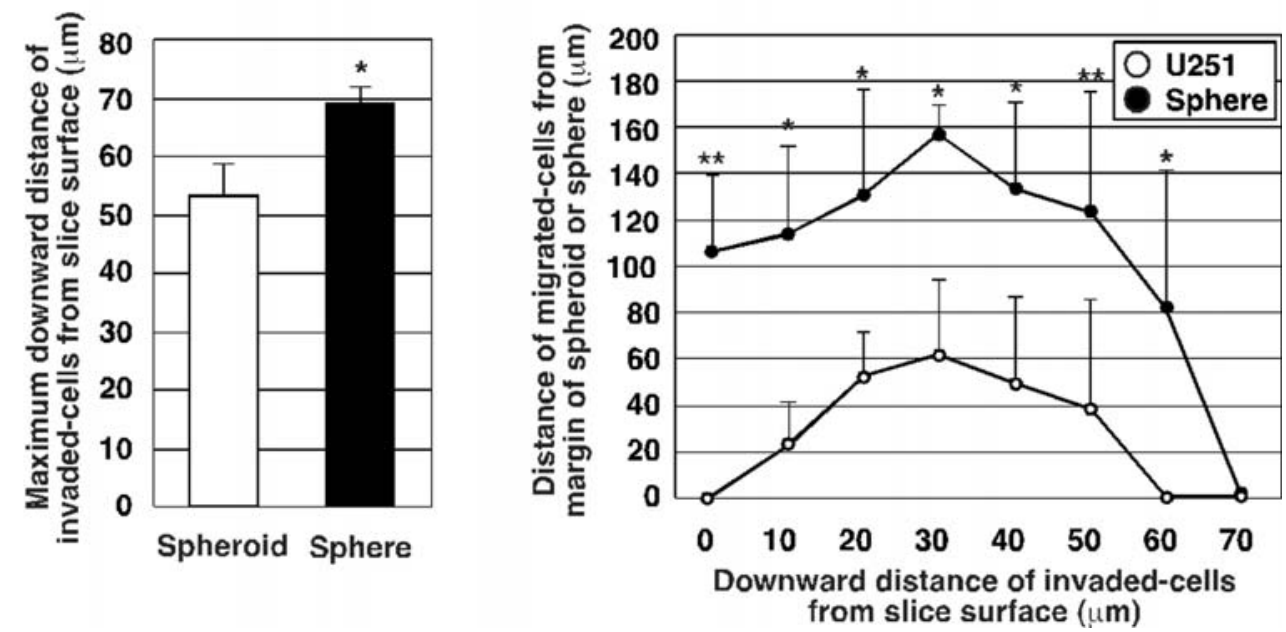

Figure 3. Invasive behavior of U251 cells and tumor spheres on rat brain slices. (A) The procedures for assessing tumor cell migration and invasion in cocultured brain slices are illustrated. A spheroid and tumor sphere derived from GFP-U251 is placed on the corpus callosum of a brain slice, and cocultured for 48 h. Phase contrast and fluorescent images are shown. (B) The migrating and invading cells, which stably expressed EGFP, were detected under CLSM. In each experiment, serial optical sections of the brain slices were obtained every $10 \mu \mathrm{m}$ from the brain slice surface $(0 \mu \mathrm{m})$ to a deeper site ( $70 \mu \mathrm{m})$. Representative photographs of invading cells are shown. Scale bar, $50 \mu \mathrm{m}$. (C) The distance from the brain slice surface was calculated. ${ }^{*} \mathrm{P}<0.005$. (D) The maximal distance of migrating cells from the margin of the spheroid or tumor sphere in each optical-section was calculated. Each column in (C) and (D) represents the mean $\pm \mathrm{SD}$ of three independent experiments. ${ }^{*} \mathrm{P}<0.05 ;{ }^{* *} \mathrm{P}<0.01$. 
A

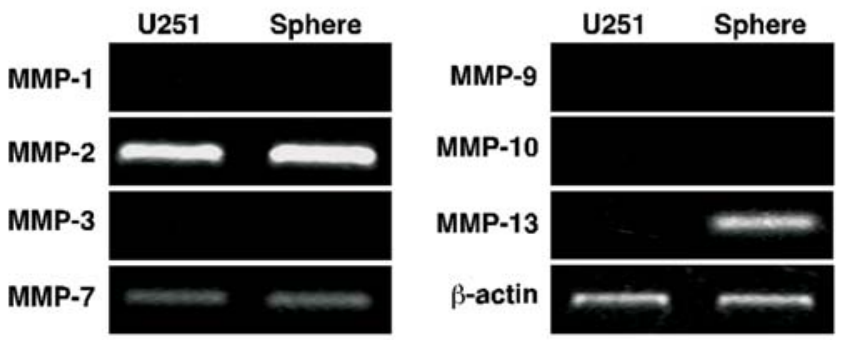

B

\begin{tabular}{|c|c|c|c|c|c|c|}
\hline & \multicolumn{2}{|c|}{ GBM-1 } & \multicolumn{2}{|c|}{ GBM-11 } & \multicolumn{2}{|c|}{ GBM-M } \\
\hline & Primary & Sphere & Primary & Sphere & Primary & Sphere \\
\hline MMP-13 & & 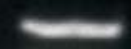 & & Q & & 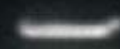 \\
\hline$\beta$-actin & & & . & سمس & & \\
\hline
\end{tabular}

C

D

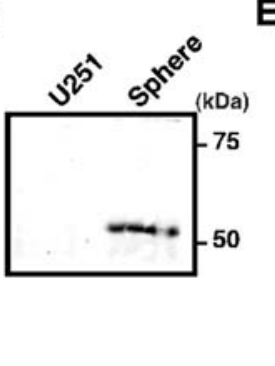

$\mathbf{E}$
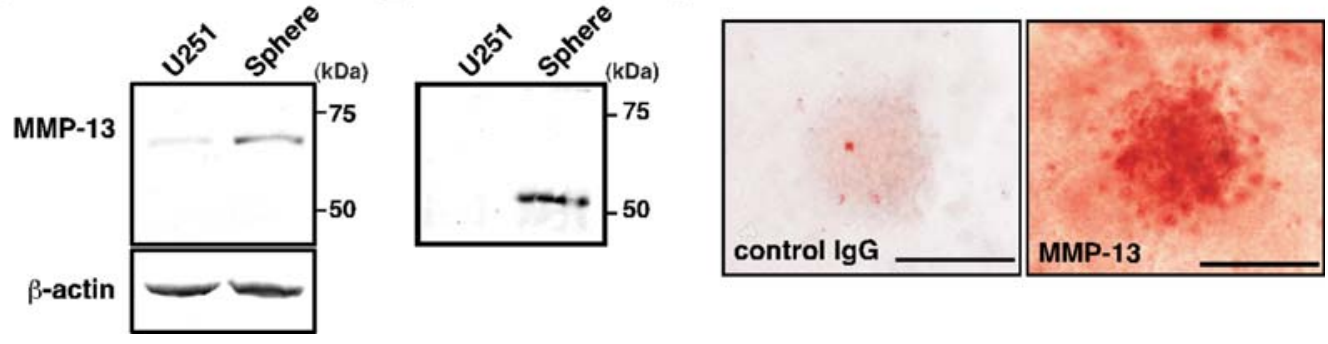

Figure 4. Expression of MMPs by tumor spheres. (A) MMP mRNA expression by U251 cells and tumor spheres was analyzed by RT-PCR. Representative data are shown. (B) MMP-13 mRNA expression by tumor spheres derived from three human GBM tissues was analyzed by RT-PCR. Representative data are shown. (C) Western blot analysis of MMP-13 protein level in cell lysates of U251 and tumor spheres. ß-actin was used as a loading control. (D) Secreted and activated MMP-13 protein was immunoprecipitated from the medium conditioned by U251 cells or tumor spheres. (E) Tumor spheres from EGFP-U251 cells cultured on rat brain slices for $48 \mathrm{~h}$ were immunohistochemically stained using a rabbit control IgG or a polyclonal anti-MMP-13 antibody. Representative photographs are shown. Migrated cells expressed MMP-13. Scale bar, $200 \mu \mathrm{m}$.

A

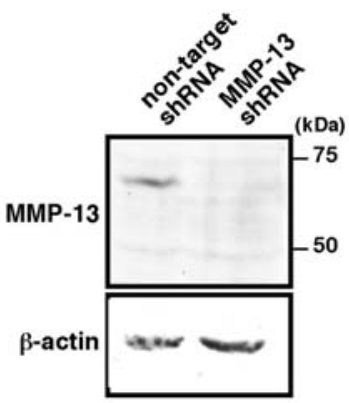

B

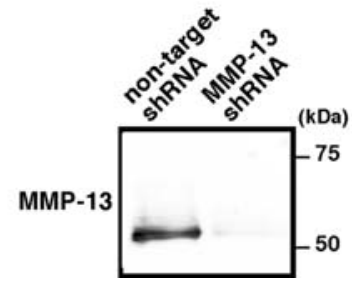

C

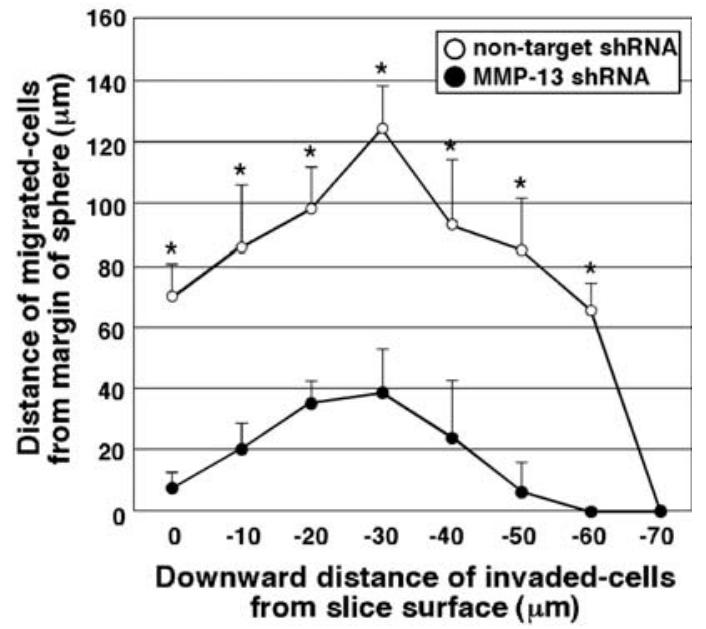

Figure 5. Effect of MMP-13 supression by shRNA on the migratory and invasive ability of tumor spheres on brain slices. (A) The protein levels of MMP-13 in cell lysates of tumor spheres transfected with non-target control or MMP-13 shRNA. (B) Secreted and activated MMP-13 protein in the medium conditioned by tumor spheres in (A) was immunoprecipitated. (C) A non-target control or MMP-13 knockdowned tumor sphere was cultured on brain slices for $48 \mathrm{~h}$. The migrating and invasive cells were analyzed in the same manner as those in Fig. 3. Each column represents the mean \pm SD of three independent experiments. " $\mathrm{P}<0.001$. 
tumor sphere-forming cells derived from three human GBM tissue (Fig. 4B). MMP-13 protein is secreted as a latent form and converted into an activated form in the extracellular milieu. Tumor spheres expressed pro-MMP-13 at a higher level than U251 cells, and the activated form was detected only in the medium conditioned by tumor spheres as revealed by immunoprecipitation using anti-MMP-13 antibody (Fig. 4C and D). To examine whether MMP-13 was expressed by invading spheres, immunohistochemical staining was performed on the brain slice after $48 \mathrm{~h}$ of coculture. As shown in Fig. 4E, migrating cells from the tumor sphere were immunopositive for MMP-13.

To investigate the functional involvement of MMP-13 in the highly motile and invasive nature of tumor spheres, we established tumor spheres which endogenous MMP-13 expression was knocked down by shRNA (Fig. 5A and B). The brain slice analysis showed that shRNA-mediated knockdown of MMP-13 was strongly suppressed the migration and invasion ability of tumor spheres (Fig. 5C).

\section{Discussion}

The concept that unregulated stem cells produce certain cancers is based on the similarities between CSCs and somatic stem cells, such as the capacity for self-renewal, proliferation, and differentiation into multiple cell types. This concept was firstly found in acute myeloid leukemia (21), and was then also evident in solid tumors, such as glioma, breast cancer, prostate cancer, lung cancer and colon cancer $(2,3,22-26)$. CSCs as the CD133-positive cells, the side population (SP) cells, and the tumor sphere-forming cells have also been isolated from many established cancer cell lines such as those of glioblastoma/glioma, neuroblastoma, adenocarcinoma, hepatocellular carcinoma, and breast cancer (27-31). However, since many cancer cell lines established from primary tumors have been maintained in vitro for many years, the existence of a cell with stem-like properties in cell lines is still a matter of debate.

In this study, we isolated and characterized CSCs from the U251 cell line, and assessed their migratory and invasive potential. We first demonstrated that the combination of EGF, bFGF, and PDGF allows U251 to form tumor spheres, leading to isolation of cancer stem-like cells. In addition to EGF and bFGF, PDGF has been shown to contribute to glial oncogenesis (32). Therefore, PDGF was also added to the sphere medium as a mitogen to maintain cancer stem-like cells, as reported with other glioma cell lines (27). The existence of CSCs in U251 cell line was confirmed by the formation of tumor spheres with the self-renewal potential in the sphere medium. In addition to CD133 and nestin expression in tumor spheres, stemness-related genes. As the aberrant activation of self-renewal is one of the key properties in CSCs, stemness-related genes in embryonic stem (ES) cells, especially Oct-3/4, which is one of a key regulator of self-renewal $(33,34)$, have been suggested to involve in the acquisition of CSC properties. The expression of Oct-3/4 has also been shown in various human solid tumors and cancer cell lines, and higher expression correlates with tumor progression, malignancy, and prognosis (35). Du et al recently reported that the expression levels of Oct-3/4 positively correlated with the grade of gliomas, and that Oct-3/4 was necessary to maintain rat C6 glioma cells in an undifferentiated state (36). Therefore, its expression may be implicated in the acquisition of stem-like properties, especially self-renewal, in tumor sphere-forming cells.

We also consider the other possibility that non-CSCs could generate CSCs in tumor spheres, that is, parental U251 cells could undergo dedifferentiation or re-programming under stem cell culture conditions. We and another group demonstrated that Bmil was highly expressed in tumor sphere-forming cells (31). Bmil is a member of the mammalian Polycomb Group family of genes and has been reported to play an important role in the self-renewal of somatic stem cells by suppressing tumor suppressor genes (37-39). Interestingly, Bachoo et al have reported that when terminally differentiated astrocytes with the deletions of $\mathrm{p} 16^{\mathrm{INK} 4 \mathrm{a}}$ and $\mathrm{p} 19^{\mathrm{ARF}}$, downstream target of Bmi1, were cultured in serum-free stem cell medium, they dedifferentiated into cancer stem-like cells to be the cell-of-origin of malignant glioma (40). Furthermore, additional reports indicate that Oct-3/4, Sox-2, and Klf-4 may be the major factors to reprogram differentiated cells into germline-competent-induced pluripotent stem cells $(41,42)$. Indeed, shRNA-mediated Oct-3/4 suppression in U251 cells significantly interfered tumor sphere formation. Barely floating tumor spheres devoid of Oct-3/4 could not keep spheres and differentiated into attached glioma-like cells (unpublished data). Therefore, only U251 cells that can highly express stemness-related genes, such as Bmil and Oct-3/4, under serum-free culture conditions might be able to acquire stem-cell-like properties through re-programming.

Unlike most other tissue, the brain is largely free of a well-defined ECM, but ECM proteins are present in the border area between normal brain and glioma cells (7). MMPs have been strongly implicated as mediators of the invasive properties of brain tumors and tumors of other organs. In addition, we and other groups showed that glioma cells are able to secrete various MMPs $(10,13)$. However, the expression of MMP-13 has not been well demonstrated in human gliomas to date. In this study, production and activity of MMP-13, but not of MMP-2 and MMP-9, were notably higher in tumor sphere-forming cells than in parental U251 cells. The motility and invasive activity of tumor sphereforming cells correlated strongly with elevated MMP-13 production. It is of interest that Oct-3/4 leads to up-regulation of MMP-13 production in bladder cancer cells (43). Furthermore, CSCs are found on the invasive front of solid tumors (44). In light of these reports, the highly invasive potential of GBM cells may be due to MMP-13 expression by CSCs under the regulation of Oct-3/4.

Stem cells of various tissues are maintained within a microenvironment, so-called niche, composed of several differentiated cell types (45). Calabrese et al clearly demonstrated that brain tumor microvasculature forms a niche that is critical for the maintenance of CD133/nestin-positive CSCs (46). Thus, MMP-13 might be required for CSCs to detach from a perivascular niche by degrading the basement membrane of tumor microvasculature. Further studies are necessary to clarify these assumptions.

CSCs are considered responsible for tumor metastasis, escape from anticancer therapies and tumor recurrence. 
Although the precise role of MMP-13 in CSCs in vivo remains unknown, the accelerated invasion of CSCs may be attributable to the activation of MMP-13. Therefore, CSCs with high MMP-13 activity may be the case of the highly invasive potential of GBM cells, as suggested in this study. Thus, inhibition of MMP-13 activity may provide a novel target in brain tumors.

\section{Acknowledgements}

We thank Dr Kenji Kameda (Integrated Center for Science, Ehime University) for technical assistance in FACS analysis. This research was supported by KAKENHI; Grant-in-Aid for Young Scientists (B) No. 21791366 to H. Takahashi.

\section{References}

1. Dalerba P, Cho RW and Clarke MF: Cancer stem cells: models and concepts. Annu Rev Med 58: 267-284, 2007.

2. Singh SK, Clarke ID, Terasaki M, Bonn VE, Hawkins C, Squire J and Dirks PB: Identification of a cancer stem cell in human brain tumors. Cancer Res 63: 5821-5828, 2003.

3. Singh SK, Hawkins C, Clarke ID, Squire JA, Bayani J, Hide T, Henkelman RM, Cusimano MD and Dirks PB: Identification of human brain tumour initiating cells. Nature 432: 396-401, 2004

4. Bao S, Wu Q, McLendon RE, Hao Y, Shi Q, Hjelmeland AB, Dewhirst MW, Bigner DD and Rich JN: Glioma stem cells promote radioresistance by preferential activation of the DNA damage response. Nature 444: 756-760, 2006

5. Jordan CT, Guzman ML and Noble M: Cancer stem cells. N Engl J Med 355: 1253-1261, 2006.

6. Demuth T and Berens ME: Molecular mechanisms of glioma cell migration and invasion. J Neurooncol 70: 217-228, 2004.

7. Rao JS: Molecular mechanisms of glioma invasiveness: the role of proteases. Nat Rev Cancer 3: 489-501, 2003.

8. Yong VW, Power C, Forsyth P and Edwards DR: Metalloproteinases in biology and pathology of the nervous system. Nat Rev Neurosci 2: 502-511, 2001

9. Yamamoto M, Mohanam S, Sawaya R, Fuller GN, Seiki M, Sato H, Gokaslan ZL, Liotta LA, Nicolson GL and Rao JS Differential expression of membrane-type matrix metalloproteinase and its correlation with gelatinase A activation in human malignant brain tumors in vivo and in vitro. Cancer Res 56: 384-392, 1996.

10. Van Meter TE, Rooprai HK, Kibble MM, Fillmore HL, Broaddus WC and Pilkington GJ: The role of matrix metalloproteinase genes in glioma invasion: co-dependent and interactive proteolysis. J Neurooncol 53: 213-235, 2001.

11. Binder DK and Berger MS: Proteases and the biology of glioma invasion. J Neurooncol 56: 149-158, 2002.

12. Nakano A, Tani E, Miyazaki K, Yamamoto Y and Furuyama J: Matrix metalloproteinases and tissue inhibitors of metalloproteinases in human gliomas. J Neurosurg 83: 298-307, 1995.

13. Lampert K, Machein U, Machein MR, Conca W, Peter HH and Volk B: Expression of matrix metalloproteinases and their tissue inhibitors in human brain tumors. Am J Pathol 153: 429-437, 1998.

14. Yeh WL, Lu DY, Lee MJ and Fu WM: Leptin induces migration and invasion of glioma cells through MMP-13 production. Glia 57: 454-464, 2009

15. Platten M, Wick W and Weller M: Malignant glioma biology: role for TGF- $\beta$ in growth, motility, angiogenesis, and immune escape. Microsc Res Tech 52: 401-410, 2001.

16. Takahashi H, Matsumoto H, Smirkin A, Itai T, Nishimura $Y$ and Tanaka J: Involvement of heparanase in migration of microglial cells. Biochim Biophys Acta 1780: 709-715, 2008.

17. Takahashi H, Matsumoto H, Kumon Y, Ohnishi T, Freeman C, Imai $\mathrm{Y}$ and Tanaka J: Expression of heparanase in nestinpositive reactive astrocytes in ischemic lesions of rat brain after transient middle cerebral artery occlusion. Neurosci Lett 417: 250-254, 2007
18. Ohnishi T, Matsumura H, Izumoto S, Hiraga S and Hayakawa T: A novel model of glioma cell invasion using organotypic brain slice culture. Cancer Res 58: 2935-2940, 1998.

19. Matsumura H, Ohnishi T, Kanemura Y, Maruno M and Yoshimine T: Quantitative analysis of glioma cell invasion by confocal laser scanning microscopy in a novel brain slice model. Biochem Biophys Res Commun 269: 513-520, 2000.

20. Kleihues P, Soylemezoglu F, Schäuble B, Scheithauer BW and Burger PC: Histopathology, classification, and grading of gliomas. Glia 15: 211-221, 1995.

21. Lapidot T, Sirard C, Vormoor J, Murdoch B, Hoang T, Caceres-Cortes J, Minden M, Paterson B, Caligiuri MA and Dick JE: A cell initiating human acute myeloid leukaemia after transplantation into SCID mice. Nature 367: 645-648, 1994.

22. Al-Hajj M, Wicha MS, Benito-Hernandez A, Morrison SJ and Clarke MF: Prospective identification of tumorigenic breast cancer cells. Proc Natl Acad Sci USA 100: 3983-3988, 2003.

23. Collins AT, Berry PA, Hyde C, Stower MJ and Maitland NJ: Prospective identification of tumorigenic prostate cancer stem cells. Cancer Res 65: 10946-10951, 2005.

24. Kim CF, Jackson EL, Woolfenden AE, Lawrence S, Babar I, Vogel S, Crowley D, Bronson RT and Jacks T: Identification of bronchioalveolar stem cells in normal lung and lung cancer. Cell 121: 823-835, 2005

25. O'Brien CA, Pollett A, Gallinger S and Dick JE: A human colon cancer cell capable of initiating tumour growth in immunodeficient mice. Nature 445: 106-110, 2007.

26. Ricci-Vitiani L, Lombardi DG, Pilozzi E, Biffoni M, Todaro M, Peschle $C$ and De Maria R: Identification and expansion of human colon-cancer-initiating cells. Nature 445: 111-115, 2007.

27. Kondo T, Setoguchi T and Taga T: Persistence of a small subpopulation of cancer stem-like cells in the C6 glioma cell line. Proc Natl Acad Sci USA 101: 781-786, 2004.

28. Setoguchi T, Taga T and Kondo T: Cancer stem cells persist in many cancer cell lines. Cell Cycle 3: 414-415, 2004.

29. Shi GM, Xu Y, Fan J, Zhou J, Yang XR, Qiu SJ, Liao Y, Wu WZ, Ji Y, Ke AW, Ding ZB, He YZ, Wu B, Yang GH, Qin WZ, Zhang W, Zhu J, Min ZH and Wu ZQ: Identification of side population cells in human hepatocellular carcinoma cell lines with stepwise metastatic potentials. J Cancer Res Clin Oncol 134: 1155-1163, 2008

30. Mahller YY, Williams JP, Baird WH, Mitton B, Grossheim J, Saeki Y, Cancelas JA, Ratner N and Cripe TP: Neuroblastoma cell lines contain pluripotent tumor initiating cells that are susceptible to a targeted oncolytic virus. PLoS One 4: e4235, 2009.

31. Qiang L, Yang Y, Ma YJ, Chen FH, Zhang LB, Liu W, Qi Q, Lu N, Tao L, Wang XT, You QD and Guo QL: Isolation and characterization of cancer stem like cells in human glioblastoma cell lines. Cancer Lett 279: 13-21, 2009.

32. Dai C, Celestino JC, Okada Y, Louis DN, Fuller GN and Holland EC: PDGF autocrine stimulation dedifferentiates cultured astrocytes and induces oligodendrogliomas and oligoastrocytomas from neural progenitors and astrocytes in vivo. Genes Dev 15: 1913-1925, 2001.

33. Okamoto K, Okazawa H, Okuda A, Sakai M, Muramatsu M and Hamada $\mathrm{H}$ : A novel octamer binding transcription factor is differentially expressed in mouse embryonic cells. Cell 60: 461-472, 1990.

34. Rosner MH, Vigano MA, Ozato K, Timmons PM, Poirier F, Rigby PW and Staudt LM: A POU-domain transcription factor in early stem cells and germ cells of the mammalian embryo. Nature 345: 686-692, 1990.

35. Monk $\mathrm{M}$ and Holding C: Human embryonic genes re-expressed in cancer cells. Oncogene 20: 8085-8091, 2001.

36. Du Z, Jia D, Liu S, Wang F, Li G, Zhang Y, Cao X, Ling EA and Hao A: Oct4 is expressed in human gliomas and promotes colony formation in glioma cells. Glia 57: 724-733, 2009.

37. Pomerantz J, Schreiber-Agus N, Liégeois NJ, Silverman A, Alland L, Chin L, Potes J, Chen K, Orlow I, Lee HW, CordonCardo $\mathrm{C}$ and De Pinho RA: The Ink4a tumor suppressor gene product, p19Arf, interacts with MDM2 and neutralizes MDM2's inhibition of p53. Cell 92: 713-723, 1998.

38. Jacobs JJ, Kieboom K, Marino S, DePinho RA and van Lohuizen M: The oncogene and Polycomb-group gene bmi-1 regulates cell proliferation and senescence through the ink4a locus. Nature 397: 164-168, 1999. 
39. Park IK, Qian D, Kiel M, Becker MW, Pihalja M, Weissman IL, Morrison SJ and Clarke MF: Bmi-1 is required for maintenance of adult self-renewing haematopoietic stem cells. Nature 423: 302-305, 2003

40. Bachoo RM, Maher EA, Ligon KL, Sharpless NE, Chan SS, You MJ, Tang Y, De Frances J, Stover E, Weissleder R Rowitch DH, Louis DN and De Pinho RA: Epidermal growth factor receptor and Ink4a/Arf: convergent mechanisms governing terminal differentiation and transformation along the neural stem cell to astrocyte axis. Cancer Cell 1: 269-277, 2002.

41. Takahashi $\mathrm{K}$ and Yamanaka S: Induction of pluripotent stem cells from mouse embryonic and adult fibroblast cultures by defined factors. Cell 126: 663-676, 2006.

42. Takahashi K, Tanabe K, Ohnuki M, Narita M, Ichisaka T, Tomoda $\mathrm{K}$ and Yamanaka S: Induction of pluripotent stem cells from adult human fibroblasts by defined factors. Cell 131: 861-872, 2007
43. Chang CC, Shieh GS, Wu P, Lin CC, Shiau AL and Wu CL: Oct-3/4 expression reflects tumor progression and regulates motility of bladder cancer cells. Cancer Res 68: 6281-6291, 1998.

44. Hermann PC, Huber SL, Herrler T, Aicher A, Ellwart JW, Guba M, Bruns CJ and Heeschen C: Distinct populations of cancer stem cells determine tumor growth and metastatic activity in human pancreatic cancer. Cell Stem Cell 1: 313-323, 2007.

45. Barami K: Relationship of neural stem cells with their vascular niche: implications in the malignant progression of gliomas. J Clin Neurosci 15: 1193-1197, 2008.

46. Calabrese C, Poppleton H, Kocak M, Hogg TL, Fuller C, Hamner B, Oh EY, Gaber MW, Finklestein D, Allen M, Frank A, Bayazitov IT, Zakharenko SS, Gajjar A, Davidoff A and Gilbertson RJ: A perivascular niche for brain tumor stem cells. Cancer Cell 11: 69-82, 2007. 